Pakistan Journal of Humanities and Social Sciences

January - March 2018, Volume 6, No. 1, Pages 17 - 29

\title{
Dividend Policy and Share Price Volatility of Nigerian Oil and Gas Industries
}

\author{
Adamu Danlami Ahmed ${ }^{l}$ \\ ${ }^{1}$ Department of Accounting, Gombe State University, Gombe State, Nigeria \\ Email: adamud.ahmed@gmail.com \\ Contact: +2348030643441
}

\begin{abstract}
This work aimed at assessing the Effect of dividend policy on share price volatility of downstream sector of Oil and Gas Company in Nigeria. The population of the study comprised all the twelve (12) quoted oil and gas downstream sector on the Nigerian Stock Exchange as o December 2016, it covered the period of 5 years from 2011 to 2015. Four (4) companies were selected as sample due to the availability of data. The study employed expost facto research design; secondary data were collected from a sample of the study. The descriptive statistic, diagnostic test, correlation and multiple regressions were employed. The study found that dividend policy affects the share price volatility significantly. This result supports the Gordon Theory of dividend, which asserts that dividend payment is relevant and affects the share price of a company.
\end{abstract}

Keywords: $\quad$ Share Price, Volatility, Dividend Policy, Nigeria

\section{Introduction}

Three major decisions are vital for any organization to excel: investment decisions, financing decisions and dividend policy decisions. The most vital and controversial among them is the dividend policy decision. The controversy started from the Black (1961) puzzle "The harder we look at the dividend picture, the more it seems like a puzzle, with pieces that don't fit together", it further comes to the Irrelevance dividend policy of M and M (1961) lastly, Relevance theory of dividend by Gordon and Lintner (1964) which propose that is better you collect your dividend now than to wait for a long time for anticipating of capital gain. All these controversies are melded toward answering whether dividend payment is relevance? And how it affects the market price of an organization?

The concept 'dividend' originates from the Latin word "Dividend" meaning "that which is to be divided". This allocation is a drive from the returns generated by removing all 
operating cost, provision for taxation, and posting to statutory reserve from the total proceeds of the business (Agarwal, 2003).

So also, the dividend can be view as a fraction of the profits of a business, which is to be disseminated amongst the owners of the business. It may, therefore, he refers to as the share that shareholders get from the company, out of its income, on their shareholdings (Purmessur \& Boodhoo, 2009).

The instability of share price, conversely, is the general risk faced by owners who own equity investment (Guo, 2002). Most shareholders are always risk-averse, and the instability of their savings is important to them since it is a measure of the level of risk they are bare to (Chijoke \& Aruoriwo, 2011).

Stock price volatility is a sign that is most frequently used by options traders to discover changes in trends in the market environment. The increase or decrease in volatility results from changes in investors emotions in the marketplace. More especially when there is the latest information released in the markets. Stock price volatility tends to rise; the reason for it rise is the result of new information released in the market which definitely changes the thinking of the shareholders.

The link between the dividend policy and share price volatility has been explored at different times by different researchers (Adesola \& Okwong, 2009; Akujoubi \& Nmandi, 2010; Samuel \& Gbeji, 2010; Ilaboya \& Aggreh 2013; Adolplus 2014). Likewise, a series of dividend theories are in existence that tried to shed more light on the topic under study. Among them is clientele effect, the information or signalling effect, and the bird-in-hand theory (Chijoke \& Aruoriwo, 2011). These studies were conducted in the developed and underdeveloped countries. Among those who found no evidence of a relationship between the dividend policy and share price in the developed market include the work of Dave and Rachim (2010) conducted in Australia and Sayed and Umara (2016) in Malaysia. On the other hand, some found a significant relationship between the variables (Zakaria, Muhammad \& Zulkifli, 2012) in Malaysia.

Furthermore, in a developing market like Nigeria, some studies were conducted. (Adesola \& Okwong, 2009; Akujoubi \& Nmandi, 2010; Samuel \& Gbegi, 2010; Ilaboya \& Aggreh, 2013; Adolplus, 2014 and Egbeonu, Paul \& Ubani, 2016) found a significant relationship. While Okafor and Mgbamea (2011) found no relationship.

It is in the line with the above that this paper seeks to observe the effect of dividend policy on share price volatility of downstream sector of Oil and Gas Company in Nigeria. The 
paper is divided into four parts. The first part contains the introduction, part two deals with a literature review of the topic, part three methodology and part four concludes the paper.

\section{Literature Review}

\section{A. Concept of Dividend Policy Share Price}

Dividend policy is the practice that management follows in making dividend payout decisions of an organization. It is how much should be given as divided and the residual to retain for further investment. Dividend policy got to do with financial policies concerning paying cash dividend now or delaying until a further date to appreciate. Whether to give out dividends now, how much, is mainly base on the company's income (excess cash) and subjective by the company's long-term earning power (Niharika \& Sarika, 2015). When excess cash exists and is not needed now, the management is expected to pay out some or all of those surplus earnings in the form of cash dividends or to buyback share from the existing shareholder in other to increase the market value of the company (Niharika \& Sarika, 2015). These entail that organizations should look which among dividend policy will maximize shareholders fund to embark on.

According to Akinsulere (2014) dividend policy can be classified as 1. Residual dividend policy: where dividend a paid as a residual after all viable capital project is embarked. 2. Active policy: under this policy, dividends are paid before investment in any viable project. 3. Hybrid policy: the policy lies in the active and passive, I which both the policy can be used concurrently.

\section{B. Empirical Review of Dividend Policy and Share Price}

Studies on dividend policy and share price volatility cut across the globe. A lot has been written; still, the puzzle is yet to be resolved. There is a vast literature carrying the relationship between dividend policy and Share price volatility. Empirical evidence suggests that the countries with the strong efficient market are better in response where semi-strong and weak market hypothesis is concerned. However, Prior studies on the relationship between Dividend policy and Share price documented mixed results.

Among the forerunner of the topic are Miller and Modigliani (1961) who documented the irrelevancy of dividend policy, under a perfect market situation. They posit that the worth of the company is achieved by its investment and financing decisions within the best possible formation and not by dividend decision. The fundamental assumptions guiding this theory are no payment of taxes on dividend and capital gain, no cost on transaction and flotation, and all 
stakeholders in the market area price taker. A lot of academic writers concurred with $\mathrm{M} \& \mathrm{M}$ theory while other goes against such as Walter and Gordon.

Adesola and Okwon (2009) conducted a study to evaluate the observe dividend policy of a cross-section of 27 Quoted companies in Nigeria using theories tested to explain dividend behavior. It was found that dividend policy is significantly associated share price. This study was conducted 8 years ago; also the scope of the study was not well established; this warrants another study.

Likewise, Samuel and Gbegi (2010) documented a positive association connecting dividend policy and firm investment and liquidity. The study uses a regression analytical tool on the data collected from quoted financial institutions in Nigeria for the period of 2010. In a different angle, Okafor and Mabamea (2011) documented a negative relationship between the dividend policy and Share price. The study covered the period of 8 years from 1998-2005. Multiple regressions were used to analyze the data collected from Nigeria stock market.

Other studies documented a positive relationship between dividend policy and share price (Ilaboya \& Aggreh, 2013; Adolphus, 2014; Maude et al., 2015 and Egbeonu et al., 2016; Yasir, Zernigah \& Muhammad, 2012; and Profile \& Bacon, 2013). It is obvious that previous studies on Dividend policy and Share price volatility have revealed mixed results; so also, the scope covered, years and sectors covered, the current study attempts to address this imbalance.

\section{Theories of Dividend Policy}

Ordu, Enekwe and Anyanwaokoro (2014) contend that "dividend policy has been a debating issue which are documented from different part of the world ranging from the studies of Linter (1956) to Modigliani and Miller (1961) to Bhattacharya (1979) and in recent times DeAngelo et al (1996), Fama and French (2001), Al-Malkawi (2007) and Al-Najjar and Hussainey (2008).

Meanwhile, among the dividend policy in practices include:

\section{A. Modigliani and Miller's dividend irrelevance theory}

The front-runners of this theory are M \& M (1961) documented a theory that suggests that dividend policy is irrelevant, and that paid a dividend does not matter. The total market value of a firm will be the same despite whether the dividend payout ratio is higher or lower (Purmessur \& Boodhoo, 2009). Their theory was built on certain assumptions. Among them are taxation and the differing tax position of shareholders and companies can be ignored, 
perfect capital market, no flotation cost. Based on the above point, they opine that the issue of dividend policy is irrelevant

This theory suffers a lot of criticism because of these assumptions; researchers are of the view that it is not feasible in the present world.

\section{B. Bird-in-hand theory}

The founders of this theory are Gordon and Walter they documented that dividend policy affects the value of a company. Thus, an adjustment in dividend payout will result in variance in the market value of a company. Hence, there must be a best possible payout ratio.ie one that maximises the shareholders found (Pandey, 2005).

\section{Transaction Cost Theory}

This theory was founded by Rozeff (1982) who asserts that payment of dividend lowered the agency cost. However, he further documents that if the company declares it will affect the transaction cost negatively. In summary, this theory indicates that if there is large transaction cost it will reduce the quantum of dividend payout to avoid the costs of external financing (Al-Kuwari, 2009).

\section{Signaling Hypothesis}

Miller and Modigliani (1961) posit that stakeholders have ideal information about a company; this has been challenged by a lot of academic writers, as management who control the affairs of the company is the custodian of information, not the investors who are external to the company. This issue, therefore, creates a breach between managers and investors; to bridge this gap, management use dividends as a tool to communicate to shareholders (AlMalkawi, 2007). Dividend serves as a focal point to signal how good or bad a company is performing.

\section{E. Clientele Effect Theory}

In the word of Ahmad and Carlos (2008), a different pattern of dividend payment exists, likewise different need of individual existence. What will be preferred by different investors differs; this can be referred to as Clientele effects. The elderly investors (pensioners and others) would favour firms that pay a cash dividend to those that hold the funds leading to capital appreciation.

\section{Methodology}

The research design is a master plan specifying the methods and procedures for collecting and analyzing the needed information. It spells out the way and manner in which a research work is intended to be carried out. This study employed the ex-post facto research 
design were data is extracted from the annual reports and accounts of the sampled deposit money banks in Nigeria for the period 2011-2015. The population of this study comprised all downstream oil and gas sector in the Nigerian Stock exchange as at 31st December 2016. Descriptive, correlation and multiple regressions using panel data analysis are used in analyzing the data generated for the study. Also, Durbin-Watson and Baltagi-Wu LBI were run to ascertain the presence of serial correlation (autocorrelation) or not. Normal p-plot was used to check for normality of the data. Stata 13 was used to analyse the data.

\section{A. Model Specification}

The model for this study was adopted from Fawaz (2014) with some modifications. The modification is the introduction of firm size as a control variable; this was done to check the effect of the size of the company with regard to dividend payment and share price volatility. The model shall be specified in two different forms; starting from the functional form to the econometric form.

\section{Functional form of the model}

The functional form explains direct functions of the dependent variable on the independent variables:

$$
\begin{aligned}
& \mathrm{SPV}=\mathrm{f}(\mathrm{DY}, \mathrm{DPRpr}, \mathrm{FS}, \mathrm{LTD}) \\
& \mathrm{SPV}_{\mathrm{it}}=\alpha_{0}+\beta_{1} \mathrm{DY}_{\mathrm{it}}+\beta_{2} \mathrm{DPR}_{\mathrm{it}}+\beta_{3} \mathrm{LTD}_{\mathrm{it}}+\beta_{4} \mathrm{FS}_{\mathrm{it}}+\mu_{\mathrm{it}}
\end{aligned}
$$

Where, " $i$ " and " $t$ " show cross-sectional and time units, respectively, SPV is stock price volatility, $D Y$ is dividend yield, $D P R$ is dividend payout ratio, $F S$ is firm size, $L T D$ is long-term debt and " $\mu$ " is error term.

\section{B. Variables and their Measurement}

\section{Share Price volatility}

Share Price Volatility is measured using the Parkinson (1980), this method uses the value of highest and lowest stock prices. It is better because it takes into cognizance the annual closing and opening prices at a giving time. Meaning the yearly highest price of stock minus least stock price, the i.e. range is divided by the average of lowest and highest share prices, and then rising second power to it (Al-malkawi, 2007). The result will be square to transform the variance to standard deviation comparable.

\section{Dividend yield}

This is derived as the ratio of dividend per share to share price. Gross dividends are used for the computation i.e. excluding tax credits. The average was taken for all years. 


\section{Dividend Payout ratio}

This is calculated as dividends per share to earnings per share for all available years. The average overall available years was utilized.

\section{Long-term debt (debt)}

It is the ration of Long-term Debts to total assets owned by the business.

\section{Firm Size}

In measuring firm size, the study adopted the natural logarithm of total assets at the end of the year.

\section{Results and Discussions}

Table 1 shows the normality of the data under consideration. A probability value of the variables shows a figure higher than 0.05 . These suggest that all the variables are normally distributed.

Table 1: Skewness/Kurtosis tests

\begin{tabular}{|c|c|c|c|c|c|}
\hline Variable & Obs & Pr(Skewness) & Pr(Kurtosis) & adj chi2(2) & Prob > chi2 \\
\hline VOL & 20 & 0.5272 & 0.9114 & 0.42 & 0.8089 \\
\hline DY & 20 & 0.0600 & 0.1394 & 5.48 & 0.0646 \\
\hline DPR & 20 & 0.4262 & 0.6729 & 0.87 & 0.6465 \\
\hline LTD & 20 & 0.7227 & 0.0648 & 3.87 & 0.1447 \\
\hline FS & 20 & 0.0908 & 0.6698 & 3.46 & 0.1768 \\
\hline
\end{tabular}

Source: Researchers Computation (2017)

Table 2 shows the result of multicollinearity test. To determine the presence of collinearity problem, a Variance Inflation Factor (VIF) test was carried out, the results of which provide evidence of the absence of collinearity. This is because the results of the VIF test ranges from a minimum of 1.18 to a maximum of 1.38 . VIF of 5.00 can still be a proof of the absence of collinearity (Doane \& Steward, 2007; Muhammad, 2009; Barde, 2009; cited in Samaila, 2014).

Table 2: VIF Multicollinearity test

\begin{tabular}{|c|c|c|}
\hline Variable & VIF & 1/VIF \\
\hline FS & 1.38 & 0.7262 \\
\hline LTD & 1.34 & 0.7458 \\
\hline DPR & 1.22 & $0 / 8184$ \\
\hline DY & 1.18 & 0.8487 \\
\hline
\end{tabular}

Table 3 shows that the standard deviation, mean, maximum and minimum of Vol are $0.2777,-0.3411,0.21209$ and -0.8399 with an average volatility rate of $27 \%$. The mean value of Dividend yield is 0.105 , maximum of $91.5 \%$ with a minimum of -1.469 and a standard deviation of 59\%. Also, dividend payout ratio shows a mean of 1.09 , maximum of 1.91 , 
minimum of 0.489 and standard deviation of 0.346 . Long-term debt shows a mean of 0.452 , minimum of 0.103 , maximum of 0.922 and standard deviation of 0.269 . Lastly, firm size measured by the natural logarithm of total assets shows a mean of 0.891 , minimum of 0.875 , maximum of 0.902 and a standard deviation of 0.007 .

Table 3: Descriptive statistics

\begin{tabular}{|c|c|c|c|c|c|}
\hline Variables & Obs & Mean & $\begin{array}{c}\text { Standard } \\
\text { Deviation }\end{array}$ & Minimum & Maximum \\
\hline VOL & 0.3115518 & -0.341116 & 0.2777158 & -.8399149 & .2120828 \\
\hline DY & .0994973 & 0.105012 & 0.5864602 & -1.469676 & .9145437 \\
\hline DPR & 1.105402 & 1.091222 & 0.3460804 & .4889785 & 1.914863 \\
\hline LTD & 0.490216 & 0.452385 & 0.2692617 & .103182 & .9227251 \\
\hline FS & .8932798 & 0.891912 & 0.0072393 & .8755592 & .9020061 \\
\hline
\end{tabular}

Source: Researchers Computation (2017)

Table 4 shows that VOL and DY were observed to be positively correlated (0.2400). Also, DPR has a positive correlation of 0.2841 . LTD shows a negative correlated with PVOL (-0.2041). FS was positively correlated with PVOL (0.5020). The correlation coefficients result indicated that $t$ none of the variables of the study is affected by multicollinearity. Anything higher than 89\% suggests present of multicollinearity (Rozeff, 1982).

Table 4: Correlation

\begin{tabular}{|c|c|c|c|c|c|}
\hline Variables & VOL & BY & DPR & LTD & FS \\
\hline VOL & 1.0000 & & & & \\
\hline DY & 0.2400 & 1.0000 & & & \\
\hline DPR & 0.2841 & .1376 & 1.0000 & & \\
\hline LTD & -0.2041 & -0.2863 & -0.1718 & 1.0000 & \\
\hline FS & 0.5020 & -0.1731 & -0.3268 & -0.2773 & 1.0000 \\
\hline
\end{tabular}

Table 5 shows the three results; however, analysis and interpretation would only be made on the OLS and RE as the Hausman test suggests RE more efficient. The robust OLS has an R2 value of 0.596 , which indicate that $60 \%$ descriptive ability of the model for the systematic changes in the dependent variable with an adjusted value of 0.157 . The F-stat (3.14) and p-value (0.0036) indicates a significant relationship between the dependent and independent variables, as such the hypothesis could not be rejected at 5\% level of significance.

As shown, DY (Dividend yield) shows a positive of (0.173) and significant at 5\% $(\mathrm{p}=0.005)$ and this indicates that a change in dividend yield will result in a change in share price volatility. 
Table 5: Regression Table

\begin{tabular}{|c|c|c|c|c|c|c|c|c|c|c|c|c|}
\hline \multirow[b]{2}{*}{ 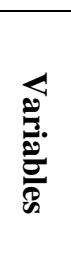 } & \multicolumn{4}{|c|}{ OLS Robust } & \multicolumn{4}{|c|}{ FIXED-EFFECT } & \multicolumn{4}{|c|}{ RANDOM-EFFECT } \\
\hline & 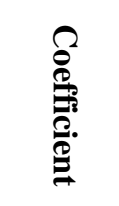 & 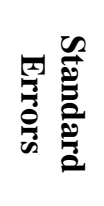 & 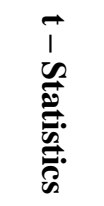 & : & 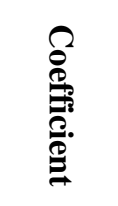 & 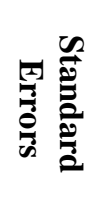 & 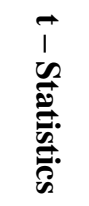 & : & 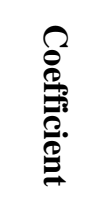 & 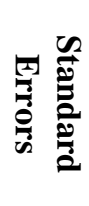 & 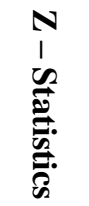 & 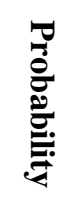 \\
\hline DY & 0.17 & 0.05 & 3.25 & 0.00 & 0.13 & 0.12 & 1.06 & 0.31 & 0.17 & 0.08 & 2.05 & 0.04 \\
\hline DPR & 0.42 & 0.14 & 2.97 & 0.01 & 0.37 & 0.17 & 2.13 & 0.05 & 0.42 & 0.14 & 2.93 & 0.00 \\
\hline LTD & 0.21 & 0.18 & 1.20 & 0.24 & 0.24 & 0.27 & 0.86 & 0.40 & 0.21 & 0.19 & 1.12 & 0.26 \\
\hline FS & 30.61 & 9.13 & 3.35 & 0.00 & 36.39 & 13.95 & 2.61 & 0.02 & 30.61 & 7.38 & 4.14 & 0.00 \\
\hline $\mathbf{C}$ & -28.22 & 8.25 & -3.42 & 0.00 & -33.33 & 12.46 & -2.67 & 0.02 & -28.22 & 6.69 & -4.22 & 0.00 \\
\hline \multicolumn{3}{|c|}{ R-squared } & \multicolumn{2}{|c|}{0.59} & \multicolumn{4}{|c|}{----} & \multicolumn{4}{|c|}{----} \\
\hline \multirow{2}{*}{\multicolumn{3}{|c|}{ F Statistics }} & \multicolumn{2}{|c|}{----} & \multicolumn{4}{|c|}{3.14} & \multicolumn{4}{|c|}{22.11} \\
\hline \multirow{2}{*}{\multicolumn{3}{|c|}{ Probability }} & \multicolumn{2}{|c|}{0.00} & \multirow{2}{*}{\multicolumn{4}{|c|}{ rob>Chi) }} & \multirow{2}{*}{\multicolumn{4}{|c|}{$\frac{0.00}{0.9845}$}} \\
\hline & & & \multicolumn{2}{|c|}{ Hausman test (Prob>Chi) } & & & & & & & & \\
\hline
\end{tabular}

Source: Researchers Computation (2017)

DPR (Dividend payout ratio) had a positive coefficient of (0.42622) and a significant level of (0.010) which implied that higher payout ratios the higher the share price volatility. However, LTD appears insignificant at 5\% $(\mathrm{p}=0.248)$ for the control variable debt. SIZE (Firm Size) was positive (30.61438) and statistically significant at $1 \%(\mathrm{p}=0.004)$ and this suggests that larger firms may have higher volatility in their share prices.

In the Random effect result, as shown in table 2, the R2 value is 0.5590 which indicate that the random effects Panel regression explains about $55.9 \%$ of the systematic variations in the dependent variable. The F-stat (22.11) and p-value (0.0002) indicate that significant linear relationship between the dependent and independent variables cannot be rejected at $5 \%$ level.

An assessment of the effects of the explanatory variables shows that DY (Dividend yield) is positive $(0.1733688)$ and significant at $5 \%(\mathrm{p}=0.040)$. This shows that dividend yield affects share price volatility, the higher the dividends yield the higher the share price volatility at 5\% level. On the other hand, control variables debt shows positive and insignificant effect, while firm size shows positive and significant effect.

\section{Discussion of Findings}

The results revealed that dividend yield and Dividend payout ratio as the proxies of dividend policy shows a positive and significant effect on share price volatility. The dividend yield has a coefficient of 0.17336 and a p-value of 0.040 , and dividend payout ratio with 0.4262 coefficients and 0.0030 as dividend payout ratio. This result refuted the M\&M theory (Irrelevance dividend theory). The finding is in line with that of Hussainey et al. (2011), 
Ilaboya and Aggreh (2013); Egbeonu, Paul and Ubani (2016). In addition, the control variable Firm size shows a positive and significant effect with share price volatility, meaning that, a larger a company with large asset has high share price volatility than a small company with the small asset. Likewise, long-term debt shows a positive and statistically insignificant relationship with share price volatility. Reveal that, an inverse relationship between debt and share price volatility. This is in line with the findings of Yasir et al. (2012) and Profilet and Bacon (2013).

\section{Summary and Recommendation}

This study empirically examined the effect of dividend policy and share price volatility of data collected from the quoted downstream sector of Nigeria oil and Gas Company. Samples of five firms were used for the study. The study used a given stock's standard deviation as the dependent variable to represent the stock's volatility as profound by Parkison (1980). Independent variables tested include dividend yield, payout ratio, size and long-term debt. As hypothesized by the literature, dividend yield and size related negatively to the stock's price volatility. Opposing the literature, leverage and growth both varied negatively with stock price volatility. The positive relationship observed between the payout ratio, dividend yield and the stock price volatility produced inconsistent results. This supported the theory of Gordon and disputed the M\&M theory. This study proposed that dividend yield and dividend payout ratio are better and more important determinant factor in determining share price volatility in the downstream sector of Nigerian Oil and Gas Company.

It was recommended that stock regulators like Nigerian stock exchange, stock brokers, underwriters, issue houses, etc... should advise companies to be prompt in dividend payment as it affects the level of price volatility positively. 
Pakistan Journal of Humanities and Social Sciences, 6(1), 2018

\section{Reference}

Adesola, W. A., \& Okwong, A. E. (2009). An Empirical Study of Dividend Policy of Quoted Companies in Nigeria. Global Journal of Social Sciences, 8 (1), 85-101.

Adolphus, J. T. (2014). An empirical test of the Dividend policy Irrelevance Hypothesis in the Nigerian context. Reseach Journal of Finance and Accounting.

Agarwal, M. R. (2003). Financial Management. RBSA Publisher.

Ahmed, H., \& Carlos, J. (2008). The Financial Factors influencing Cash Dividend Policy: A sample of U.S. Manufacturing companies. Inter Metro Business Journal Fall Vol. 4 No.2, 23.

Akinsuleri, O. (2014). Financial Management. Lagos: El-Toda ventures ltd eight edition.

Akujuobi, A. B. C. \& Nnamdi, I. (2010) Earnings-Dividend Relationship in Corporate Nigeria: A Test of Predictive Efficacy an International Multi-Disciplinary Journal, Ethiopia Vol. (4), Serial No. 17, October 2010

Al-Kuwari, D. (2009) Determinants of the Dividend Policy in Emerging Stock Exchanges: The Case of GCC Countries, Global Economy \& Finance Journal, 2(2), 38-63.

Al-malkawi, H. N., Rafferty, M., \& Pillai, R. (2010). Dividend Policy. A review of Theories and Empirical evidence. International Bulletin of Business and Business Administration, 171-200.

Black, F. (1961). The Dividend Puzzle. Journal of Portfolio Management, 5-8.

Chijoke.A.O \& Aroruiwo.M.C (2011) Dividend Policy and Share Price Volatility in Nigeria Jorind (9)1 June 2011.

Dave E. \& Rachim. V.S (2010). Dividend policy and stock price volatility: Australian evidence Applied Financial Economics.

Egon .O. , Paul.E .L. \& Ubani .G .I. (2016) Dividend Policy and Share Price Volatility: A Co-Integration Analysis. International Journal of Advanced Academic Research | Social \& Management Sciences, Vol. 2, Issue 8 (August 2016)

Fawaz .K. A. (2014) The Impact of Dividend Policy on Share Price Volatility: Empirical Evidence from Jordanian Stock Market European Journal of Business and Management, Vol.6, No.38, 2014

Gordon, M. J., 1959. "Dividends, Earnings and Stock Prices". Review of Economics and Statistics V.41 No. 2. Part 1: (May), pp. 99-105.http://www.jstor.org/stable/1927792

Guo, H. (2002), Stock market returns, volatility and future output 
Hussainey. K, Chijoke, O.M. \& Aruoriwo.M.C (2011) Dividend policy and share price volatility: UK evidence The Journal of Risk Finance Vol. 12 No. 1, 2011 pp. 57- 68.

Ilaboya, O. J. and Aggreh, M. (2013). Dividend Policy and Share Price Volatility, Journal of Asian Development Studies, 2(2), 109-122.

Khaled .H. Chijoke .O. M. \& Aruoriwo M. (2011) Dividend policy and share price volatility: UK evidence The Journal of Risk Finance Vol. 12 No. 1, 2011pp. 57-68.

Lintner, J. (1956). Dividends, Earning, Leverage, Stock price and the Supply of Capital to Corporations. The review of Economics and Statistics.

Mauda. A.k, jimoh.i.o \& Okpanachi.j (2015) dividend payout pattern: Nigeria deposit money banks in perspective European journal of accounting, auditing and finance research vol.3, no.10, pp.58-66.

Modigliani, F., \& Miller, M. (1961). Dividend Policy, Growth and the Valuation of Shares. Journal of Business Vol. 34, 411-433.

Niharika, M., \& Sarika, M. (2015). The Impact of Dividend Policy on the Market price of the share and Growth of joint stock company in Sensex. International Journal of Innovation Science.

Okafor, C. A., Mgbame, C.O., \& Chijoke-Mgbame, A. M. (2011). Dividend policy and share price volatility in Nigeria. Journal of Research in National Development, 9 (1), $202-210$.

Pandy, I. M. (2005). Financial Management. Indian: Vikas Publishing House RT Ltd.

Parkinson, M. (1980), The extreme value method for estimating the variance of the rate of Return, Journal of Business, Vol. 53, pp. 61-5.

Profilet, K. A \& Bacon, F.W. (2013) Dividend Policy and Stock Price Volatility in the U.S. Equity Capital Market Asbbs Annual Conference: Las Vegas Volume 20 Number 1

Purmessur, R. D., \& Boodhoo, R. (2009). Signalling Power of Dividend on firms future profit. International Interdisciplinary Journal.

Roze, M. S. (1982) Growth, beta and agency costs as determinants of dividend payout ratios, Journal of Financial Research, Fall, 249 \pm 59 .

Samaila, I. A. (2014). Corporate Governance and Financial Reporting quality in The Nigerian Oil Marketing Industry. Unpublished Doctoral Thesis, Department of Accounting, Bayero University Kano. 
Pakistan Journal of Humanities and Social Sciences, 6(1), 2018

Samuel .S.E And Gbegi.D.O. (2010). Dividend Policy, Liquidity Constraints And Firm Investment In Nigeria: An Empirical Analysis Continental J. Social Sciences 3: 59 64.

Sayed A. S. \& Umara N. (2016) Stock Price Volatility and Role of Dividend Policy: Empirical Evidence from Pakistan. International Journal of Economics and Financial Issues, 2016, 6(2), 461-472.

Yasir. H, Zernigah I.K, \& Muhammad A.K., (2012). "Dividend Policy and Stock price Volatility: Evidence from Pakistan." Global Journal of Management and Business Research, Vol. 12 Issue 5. pp. 78-89.

Zakaria. Z, Muhammad.J \& Zulkifli.A (2012) the impact of dividend policy on the share price volatility: Malaysian Construction and Material Companies. International Journal of Economics and Management Sciences Vol. 2, No. 5, 2012, pp. 01-08 